\title{
HMGCR Gene
}

National Cancer Institute

\section{Source}

National Cancer Institute. HMGCR Gene. NCI Thesaurus. Code C60877.

This gene plays a role in the biosynthesis of steroids. 